\title{
The role of oxygen in degradation of Hydrocarbons in sediments of an Estuary in Nigeria
}

\author{
Dike Henry Ogbuagu ${ }^{1,}$, Ebenezer Temitope Adebayo ${ }^{2}$, Emmanuel Ikechukwu Iwuchukwu $^{3}$ \\ ${ }^{1}$ Department of Environmental Technology, Federal University of Technology, PMB 1526, Owerri, Nigeria \\ ${ }^{2}$ Department of Fisheries and Aquaculture Technology, Federal University of Technology, Owerri, Nigeria \\ ${ }^{3}$ Department of Agricultural Engineering, Federal Polytechnic, Nekede, Owerri, Nigeria
}

\section{Email address:}

henrydike2002@yahoo.com (Ogbuagu D. H.), adebayotemitope.et@gmail.com (Adebayo E. T.), iwuchukwuemmanuel14@gmail.com (Iwuchukwu E. I.)

\section{To cite this article:}

Dike Henry Ogbuagu, Ebenezer Temitope Adebayo, Emmanuel Ikechukwu Iwuchukwu. The Role of Oxygen in Degradation of Hydrocarbons in Sediments of an Estuary in Nigeria. Journal of Water Resources and Ocean Science. Vol. 3, No. 4, 2014 , pp. 45-50. doi: $10.11648 /$ j.wros.20140304.11

\begin{abstract}
The rates of degradation of Aliphatic (AHs) and Polynuclear Aromatic Hydrocarbons (PAHs) in sediments of the Bonny Estuary were investigated. Degradation was enhanced by aerobic condition in the order of treatments $10000 \mathrm{ppm}>1000 \mathrm{ppm}>100 \mathrm{ppm}$ (AHs), 100ppm $>1000 \mathrm{ppm}>10000 \mathrm{ppm}$ (PAHs) than in the anaerobic condition which was in the order $10000 \mathrm{ppm}>100 \mathrm{ppm}>1000 \mathrm{ppm}$ (AHs), 100ppm $>1000 \mathrm{ppm}>10000 \mathrm{ppm}$ (PAHs). Rates of degradation differed over the harvest days $\left[\mathrm{F}_{(10.90)}>\mathrm{F}_{\text {crit(4.17) }}\right]$ and between the oxygen conditions $\left[\mathrm{F}_{(10.92)}>\mathrm{F}_{\text {crit(4.17) }}\right](\mathrm{P}<0.05)$. Degradation enhancements by oxygenation were by $9.85,63.64$ and $62.66 \%$ (AHs) and $2.07,3.15$ and $3.95 \%$ (PAHs) on Days 14,28 and 42 respectively. Rate of degradation was dose-dependent and slower especially of the PAHs.
\end{abstract}

Keywords: Degradation, Hydrocarbons, Bonny Estuary, Marine Sediments, Anoxia

\section{Introduction}

Sediments on the sea floor are formed by particulate matter that settles out of the water column, and may consist of anything from coarse gravel and sand to clay and organic ooze. In natural aquatic ecosystems, persistent organic pollutants like the toxic metals and hydrocarbons occur in low concentrations mainly due to weathering of soils and their associated bedrocks, as well as geological dispositions. However, due to human activities in recent times, there has been an unprecedented increase in the level of these pollutants, and the occurrence of such species in excess of natural load has become a problem of increasing concern not only to environmentalists but also to health practitioners.

For example, of more than 120 polluted sediment sites investigated in harbours and fjords in Norway between 19931996 alone, about 90 were heavily polluted with contaminants such as PCBs, PAHs, tributyl-triphenyl tin compounds, mercury, lead and cadmium [1]. Skei [2] and Karimov [3] have also made related observations. Contaminated sediments are most commonly found near population centres and harbours [4-9] like the Bonny Estuary in the Niger Delta, where there are many sources of pollution of various kinds. The Bonny Estuary has industrial installations, including the oil, gas, and ancillary operations facilities located proximal to the shores, and so, contamination of sediments could be a major environmental problem. According to Ogbuagu et al. $[10,11]$, pollutants in sediments can spread to the surrounding water, re-suspend when sediments are disturbed, or be absorbed by benthic organisms through bioaccumulation. Worse still, because of certain mechanisms, contaminated sediments may continue to release hazardous chemicals to the surroundings long after the land-based sources of the pollution have been eliminated. Consequently, contaminated sediments can have serious effects on living organisms [10, 12-16] and the entire ecosystems [17], including higher mortality, reduced growth rates and impaired reproductive processes in marine organisms. Because many contaminants accumulate in food chains, they can also affect human health through trophic relationships.

Sediments of marine ecosystems are usually depleted of dissolved oxygen; a condition that is generally found in areas that have restricted water exchange. In most cases, oxygen is prevented from reaching the deeper levels by a physical 
barrier such as mud [18] as well as by a pronounced density stratification in which, for instance, heavier hyper-saline waters rest at the bottom of a basin. Anoxia, among other effects could tremendously slow down the rate of biodegradation of pollutants, especially of the already persistent ones such as crude oil and petroleum pollutants. With increasing inputs of such pollutants into the Bonny Estuary by the many oil, gas, shipping, and ancillary companies, there is need to investigate the fate of such POP as petroleum hydrocarbons in a simulated anoxic and oxygenated conditions as to infer natural removal of pollutant loadings over time.

\section{Materials and Methods}

\subsection{Study Area}

Bonny Island, with hot and humid weather conditions experiences heavy rains for about 9 months in the year; with average precipitation of $3800 \mathrm{~mm}$, ambient temperature of $33^{\circ} \mathrm{C}$ during the day, and humidities of almost $100 \%$. The coastal settlement is located between latitudes $4^{\circ} 22^{\prime}$ and $4^{\circ}$ $32^{\prime} \mathrm{N}$ and longitudes $7^{\circ} 12^{\prime}$ and $7^{\circ} 18^{\prime} \mathrm{E}$ (Fig. 1). The Bonny Estuary is the main passage for merchant shipping to the inland Port of Onne and for tankers and merchant shipping going to Port Harcourt and the Nigerian National Petroleum Company refined products terminal at Okirika in the Niger Delta region of Nigeria. The estuary receives effluents and other wastes from a number of industries and ancillary companies on the Island. The Bonny Oil and Gas Terminal (BOGT), the Nigeria Liquefied Natural Gas complex (NLNG), and other service companies are all located close to the estuary.

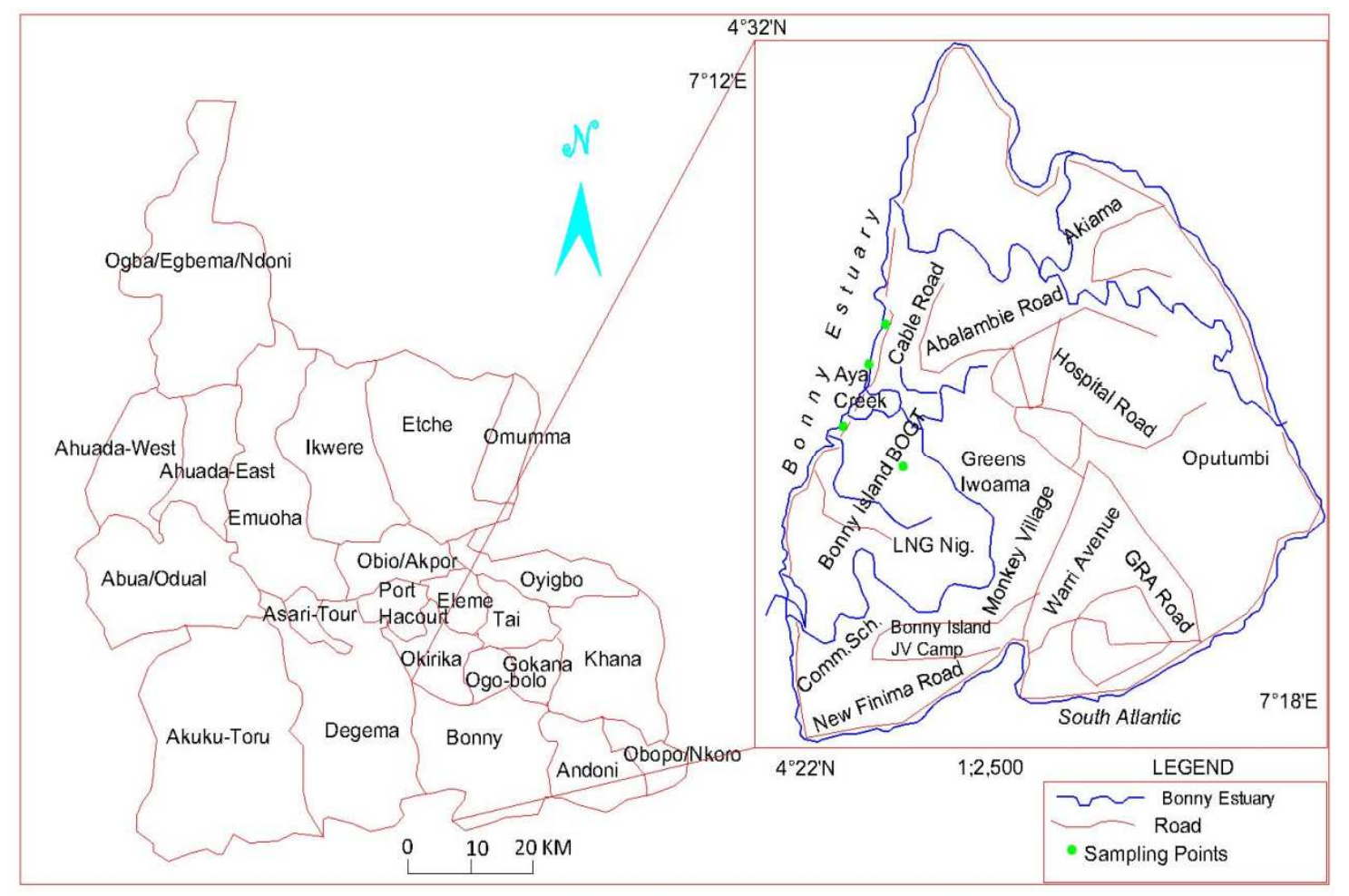

Fig 1. Map of Rivers State showing Bonny Estuary, west of the Bonny Local Government Area

\subsection{Sediment Sample Collection}

Sediments were collected from seabed at two points (Coordinates $4^{\circ} 25^{\prime} 698^{\prime \prime}$ Northing, $7^{\circ} 09^{\prime} 325^{\prime \prime}$ Easting and $4^{\circ}$ 26' 546" Northing, $7^{\circ} 09^{\prime} 475^{\prime \prime}$ Easting for Upstream and Downstream respectively) that were relatively pristine, between the NLNG and The Shell Petroleum Development Company Limited (SPDC) BOGT facility in the Estuary. A pre-grab sampler was deployed from the deck of a vessel and successive grab samples from about 20meters depth of the river were emptied into 5 liters containers completely lined internally with aluminum foil. Labeled samples were transported to the Laboratory and preserved in the refrigerator until they were needed.

\subsection{Laboratory Procedures}

\subsubsection{Test Sample}

The Bonny Light crude oil test sample was obtained from the SPDC BOGT facility and preserved in the refrigerator until when needed.

\subsubsection{Treatment of Sediment Samples}

The sediments were sieved with their habitat water through $2 \mathrm{~mm}, 1 \mathrm{~mm}$ and $0.5 \mathrm{~mm}$ sieves to remove large stones, mollusks, crustaceans and organic debris, and sieved sediments allowed to settle over night before being treated with various concentrations of crude oil.

Successive one kilogram of sieved sediments were 
weighed and mixed with pre-determined quantities of crude oil (with a total organic content of $85.4 \%$ ) in such a manner as to achieve the required concentrations of $100 \mathrm{ppm}$, $1000 \mathrm{ppm}$ and $10000 \mathrm{ppm}$. These concentrations were based on the dry weight of the sediment. The crude oil concentrations and sediments were homogenized by mixing thoroughly with a laboratory desk top mixer for about 10 minutes in increasing order of concentration. The mixture container was washed and properly cleaned prior to mixing each new treatment.

The treated and homogenized sediments were dispensed into separately labeled glass petri dishes, making sure that there were no air bubbles trapped or overflow of sediment. Each concentration was prepared for four harvest day in both anoxic and aerobic conditions.

Samples for anoxic condition monitoring were packed inside anaerobic jar while those for the aerobic condition monitoring were kept under the laboratory condition. The anaerobic jar was kept in an incubator at the temperature of $18^{\circ} \mathrm{C}$. Sediments were then harvested on Days $0,14,28$, and 42 for all the concentrations (100ppm, 1000ppm and 10000 ppm).

\subsubsection{Determination of Hydrocarbons}

Five grams of harvested sediment sample was weighed into a beaker and $10 \mathrm{~mL}$ of analytical grade hexane added to it The mixture was shaken for 5minutes, filtered, and filtrates were used for the determination of hydrocarbons using the flame ionization detector Gas Chromatography (GC). This involved setting up the GC conditions (oven temperature, detector temperature, gas flow rates) and injecting the filtrates into the GC for run prompting. For every hydrocarbon parameter measured, standards and blanks were prepared and used for calibration of the instrument. The calibrated chromatograms were used to quantify the concentration of hydrocarbons in the extracted samples.

\subsection{Statistical Analysis}

Bivariate and descriptive statistical analyses as provided by the SPSS v.17.0 and the MS Excel 2007 softwares were used to analyze data. Variation plots were used to represent degradation levels of the hydrocarbons in sediment samples over the 42 days of experiment; the one-way ANOVA was used to test for homogeneity in mean levels of degradation over the experimental period, and post-hoc structure of group means was detected with means plots at $\mathrm{P}<0.05$.

\section{Results}

\subsection{Degradation of Hydrocarbons}

Of the aliphatic hydrocarbons (AHs), the 100, 1000 and $10000 \mathrm{ppm}$ crude oil treatments degraded from 98.25, 980.28 and $9850.25 \mathrm{ppm}$ at the commencement of the experiment, through $86.45,758.45$ and 7035.74ppm on Day 14, 65.38, 608.15 and $2278.49 \mathrm{ppm}$ on Day 28 to $48.25,485.35$ and $1544.80 \mathrm{ppm}$ on Day 42 in the aerobic setup. This translates to percentage degradation rates of $12.01,22.63$ and $28.57 \%$ on Day 14, 33.46, 37.96 and $76.86 \%$ on Day 28 and 50.89, 50.49 and $83.31 \%$ on Day 42 respectively (Fig. 2).

In the anaerobic setup, degradation in the 100, 1000 and $10000 \mathrm{ppm}$ treatment concentrations proceeded from 98.25 , 980.28 and $9850.25 \mathrm{ppm}$ on Day 0 , through $98.25,880.35$ and $7763.37 \mathrm{ppm}$ on Day 14, 75.88, 784.25 and 7257.85ppm on Day 28 to $29.87,28.78$ and $51.28 \mathrm{ppm}$ on Day 42. This amounts to percentage degradations of $0.00,10.19$ and $21.19 \%$ on Day 14, 22.77, 19.99 and 27.83\% on Day 28 and 29.87, 28.78 and $51.28 \%$ on Day 42 (Fig. 3).

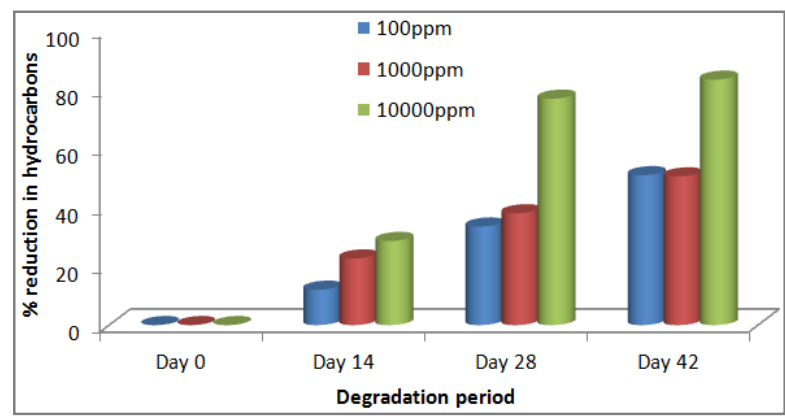

Fig 2. Mean residual concentrations of aliphatic hydrocarbons after 42 days under aerobic condition

Of the PAHs, degradation in the aerobic setups proceeded from $4.80,5.45$ and $10.84 \mathrm{ppm}$ at the commencement of the experiment through $4.35,5.30$ and $10.25 \mathrm{ppm}$ on Day 14, 4.18, 5.08 and $10.12 \mathrm{ppm}$ on Day 28 to $3.98,4.95$ and $10.05 \mathrm{ppm}$ at the end of the experiment. This gives the percentage degradation rates of $9.38,2.75$ and $1.19 \%$ on Day $14,12.92,6.79$ and $6.64 \%$ on Day 28 and 17.08, 9.17 and $7.29 \%$ at the end of the experiment (Fig. 4).

However, in the anaerobic setups, degradation in the PAHs components of the three crude oil treatments proceeded from $4.80,5.45$ and $10.84 \mathrm{ppm}$ at the commencement of experiment through $4.40,5.40$ and $10.50 \mathrm{ppm}$ on Day 14, 4.32, 5.25 and $10.45 \mathrm{ppm}$ on Day 28 to $4.28,5.10$ and $10.38 \mathrm{ppm}$ on Day 42. This translates to percentage degradations of $8.33,0.92$ and $3.14 \%$ on Day $14,10.00,3.67$ and $3.59 \%$ on Day 28 to $10.83,6.42$ and $4.24 \%$ at the end of the experiment (Fig. 5).

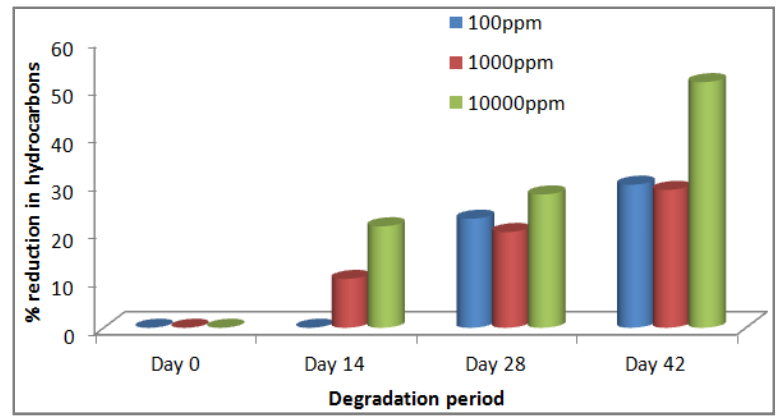

Fig 3. Mean residual concentrations of aliphatic hydrocarbons after 42 days under anaerobic condition 


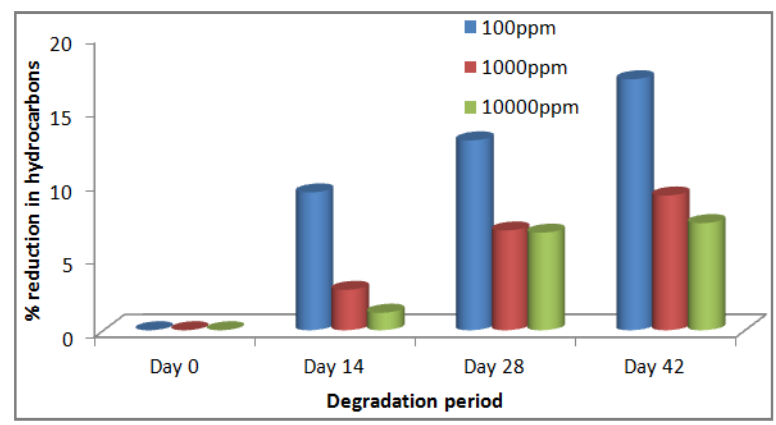

Fig 4. Mean residual concentrations of polynuclear aromatic hydrocarbons after 42 days under aerobic condition

A test of homogeneity in mean variance revealed significant difference in rates of degradation of combined hydrocarbons on each of Days 14, 28 and $42\left[\mathrm{~F}_{(10.90)}>\mathrm{F}_{\text {crit(4.17) }}\right]$ at $\mathrm{P}<0.05$.

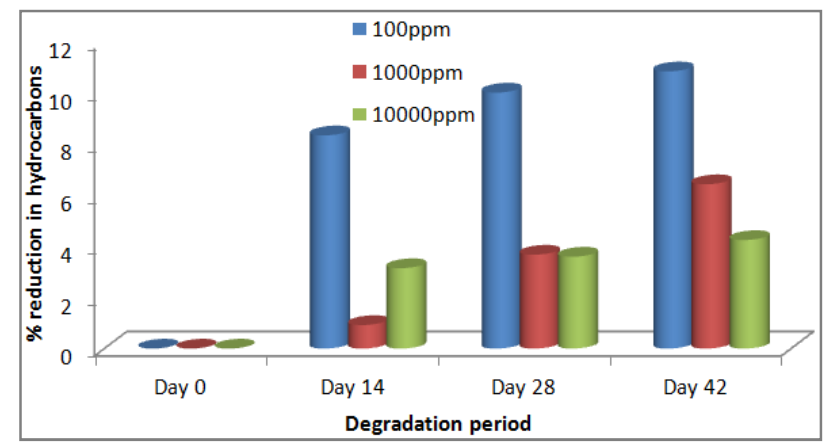

Fig 5. Mean residual concentrations of polynuclear aromatic hydrocarbons after 42 days under anaerobic condition

A post-hoc structure of group means that utilized Day 0, the commencement of the experiment as predictor variable revealed that on Day 14 (Fig. 6), Day 28 (Fig. 7) and Day 42 (Fig. 8), the aliphatic hydrocarbon treatment (3642.93 ppm concentration) contributed the heterogeneity most.

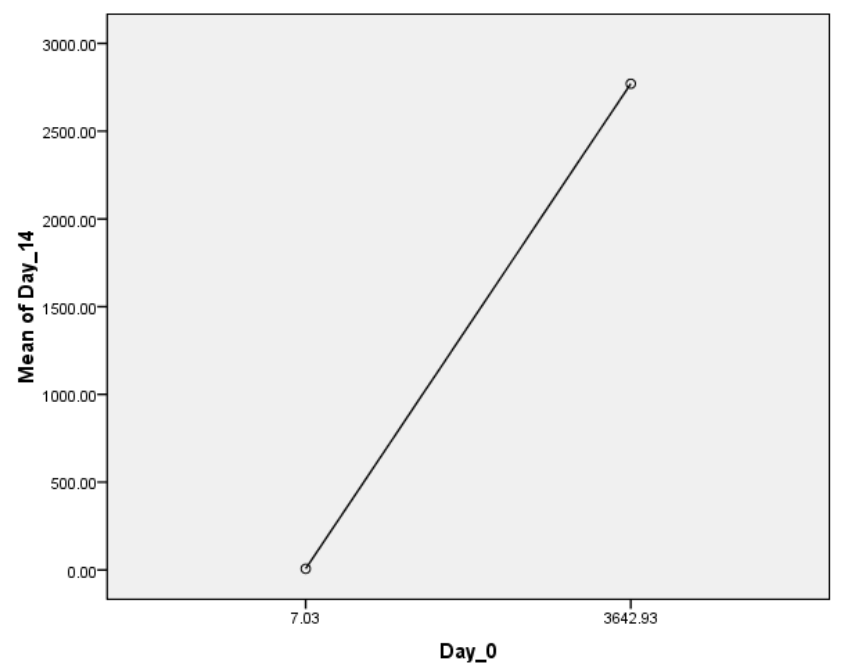

Fig 6. Means plot in rate of degradation of hydrocarbons between Day 0 and Day 14

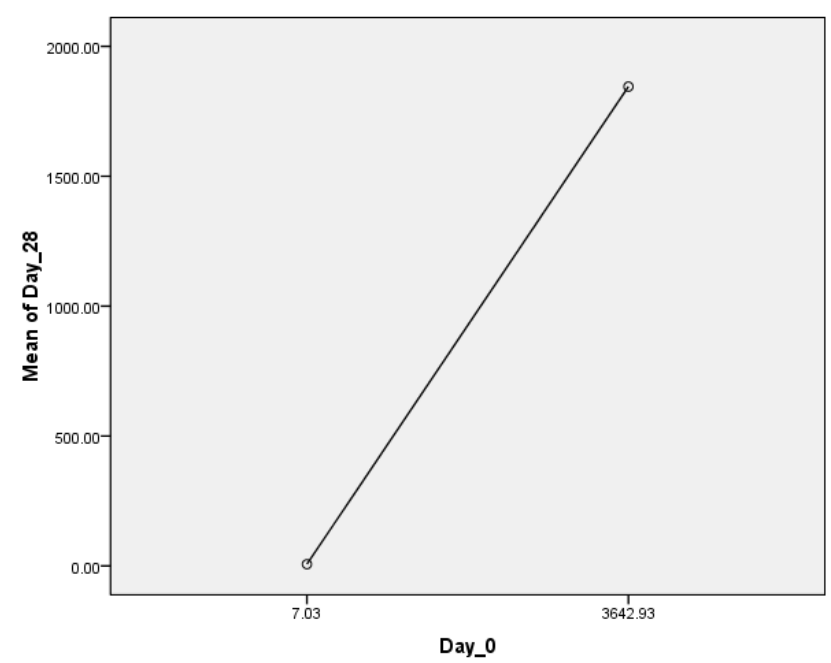

Fig 7. Means plot in rate of degradation of hydrocarbons between Day 0 and Day 28

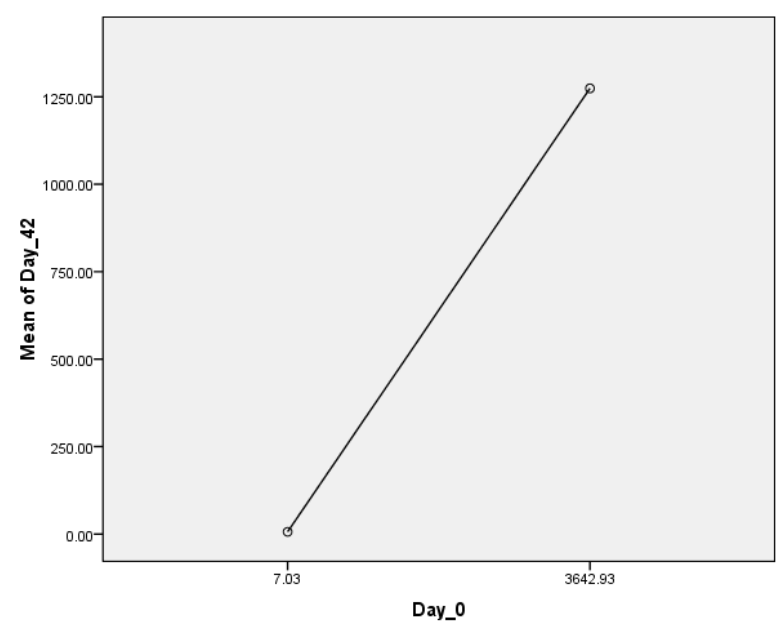

Fig 8. Means plot in rate of degradation of hydrocarbons between Day 0 and Day 42

\subsection{Comparison of Rates of Degradation under Aerobic and Anaerobic Conditions}

Mean degradations in pooled concentrations of the AHs and PAHs over the 42 days experimental period under aerobic and anaerobic conditions are presented in Table 1. In the aerobic setup, the aliphatics degraded from mean concentration of $3642.93 \mathrm{ppm}$ on Day 0, through 2626.88 ppm on Day 14, $984.01 \mathrm{ppm}$ on Day 28 to $692.80 \mathrm{ppm}$ on Day 42. However, in the anaerobic setup, they degraded through 2913.99 ppm on Day 14, 2705.99 ppm on Day 28 to 1855.34 ppm on Day 42.

Table 1. Mean concentrations of hydrocarbons in aerobic and anaerobic degradation conditions

\begin{tabular}{lllll}
\hline Hydrocarbons(ppm) & Day 0 & Day 14 & Day 28 & Day 42 \\
\hline Aliphatics (aerobic) & 3642.93 & 2626.88 & 984.01 & 692.80 \\
Aliphatics (anaerobic) & 3642.93 & 2913.99 & 2705.99 & 1855.34 \\
PAHs (aerobic) & 7.03 & 6.63 & 6.46 & 6.33 \\
PAHs (anaerobic) & 7.03 & 6.77 & 6.67 & 6.59 \\
\hline
\end{tabular}


Of the PAHs, mean concentrations degraded from 7.03ppm at the commencement of experiment, through $6.63,6.46$ to $6.33 \mathrm{ppm}$ in the aerobic setup, and $7.77,6.67$ to $6.59 \mathrm{ppm}$ in the anaerobic setup on Days 14, 28 and 42 respectively.

The One-way ANOVA test revealed significant heterogeneity in mean concentrations of the petroleum hydrocarbons treatments under aerobic and anaerobic degradation conditions $\left[\mathrm{F}_{(10.92)}>\mathrm{F}_{\text {crit(4.17) }}\right]$ at $\mathrm{P}<0.05$. Oxidation therefore enhanced the degradation of the AHs by $9.85 \%$ on Day 14, 63.64\% on Day 28 and 62.66\% on Day 42 (Fig. 9). However, in the PAHs, oxygenation enhanced degradation by $2.07 \%$ on Day $14,3.15 \%$ on Day 28 and $3.95 \%$ on Day 42 .

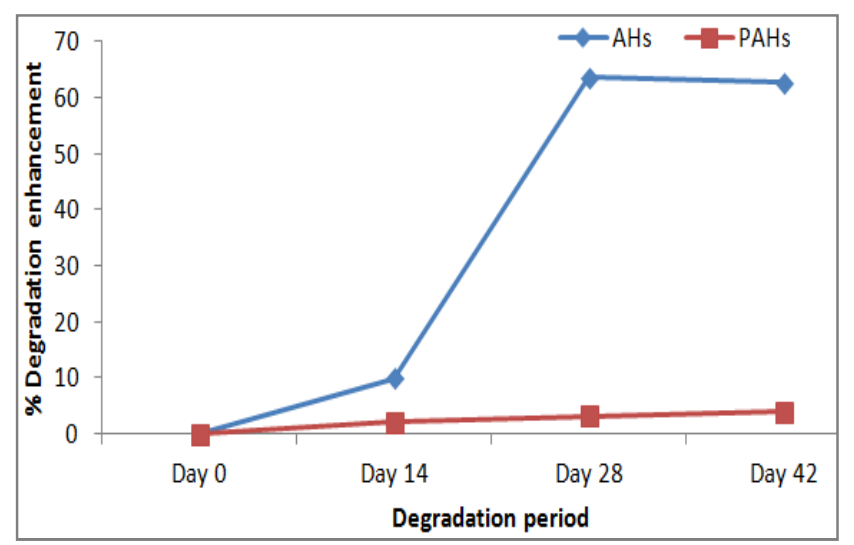

Fig 9. Percentage oxidative enhancement of degradation of the aliphatic (AHs) and polynuclear aromatic hydrocarbons (PAHs)

\section{Discussion}

The current study clearly indicates that the polynuclear aromatic hydrocarbons are more recalcitrant to biodegradation than the aliphatics, especially in anoxic conditions, as exemplified in sediments of the marine environment under simulation. The persistence of petroleum hydrocarbons, as members of the Persistent Organic Pollutants (POPs) group in sediments of Estuaries had also been noted by Unlu et al. [19] in the Ambarli Port area of the Sea of Marmara in Turkey, Chen and Chen [20] in sediments of Kaohsiung Harbor in Taiwan and Mostafa et al. [21] in sediments of the western harbour of Alexandria in Egypt.

Generally, degradation rates were slow in the 100 and $1000 \mathrm{ppm}$ aliphatic hydrocarbons treatments and even slower in all the concentrations of the polynuclear aromatic hydrocarbons. Of the aliphatic hydrocarbons in aerobic and anaerobic conditions, the 100000 ppm concentration treatment degraded fastest, followed by the 1000 and 100 ppm treatments respectively. This indicates a dose-related degradation rate of the hydrocarbons. The effects of persistent pollutants on aquatic fauna, especially in the benthic regions of have been elucidated by Ogbuagu et al. [10]. However, of the polynuclear aromatic hydrocarbons under both aerobic and anaerobic conditions, the $100 \mathrm{ppm}$ treatments degraded fastest, followed by the $10000 \mathrm{ppm}$ concentrations. This indicates an inverse dose-related pattern; a direct opposite of the degradation patterns of the aliphatic hydrocarbons category.

Degradation rates clearly differed as the period progressed from the $14^{\text {th }}$, through $28^{\text {th }}$ and to the $42^{\text {nd }}$ day of experimentation. Maximum degradations were recorded at the end of the experiments and this implies that duration or time is a determinant factor in biodegradation of pollutants in aquatic environments. However, this marked difference in degradation rates appeared to be mostly associated with the initial concentrations of the aliphatic hydrocarbons.

Oxygenation (aerobiosis) clearly aided degradation of both the aliphatic and polynuclear aromatic hydrocarbons, as confirmed by the ANOVA test. This underpins the role of oxygen in the enhancement of biodegradation process by aerobic microorganisms, and further underscores the role of oxygen in sediment pollutants detoxification and purification of water bodies.

\section{Summary}

Degradation rates of the petroleum hydrocarbons was dose-dependent and that of the polynuclear aromatic hydrocarbons was very slow in marine sediments. Rates of degradation differed markedly during the experimental period and was enhanced by aerobiosis.

\section{Conclusion}

This study revealed that petroleum hydrocarbons were persistent in the environment and that their degradations in marine sediments were enhanced by the presence of oxygen.

\section{Acknowledgements}

We are grateful to Transcontinental Petrotech Nigeria Limited for granting us participation in this study.

\section{References}

[1] Norwegian Environment Agency (NEA), Polluted marine sediments, (2009). Retrieved 25/07/2013 from http://www.environment.no/Topics/Marine-areas/Hazardouschemicals-in-coastal-waters/Polluted-marine-sediments/

[2] Skei J (2009), The entrapment of pollutants in Norwegian Fjord sediments- A beneficial situation for the North Sea, In: Holocene marine sedimentation in the North Sea Basin, S.D. Nio, R.T.E. Shüttenhelm \& Tj. C.E. Van Weering (Eds.), Blackwell Publishing Ltd., Oxford, UK. doi: 10.1002/9781444303759.ch32.

[3] Karimov M (2007), Heavy metals in the bottom sediments of the Western Norwegian fjords, MSc Thesis, Geology Department, University of Tartu, pp.122.

[4] Ahnert A and Borowski C (2000), Environmental risk assessment of anthropogenic activity in the deep sea. Jr. Aquat. Ecosyst. Stress \& Recov.; 7(4): 299. Available at http://web.ebscohost.com/ehost/pdf?vid=5\&hid=2\&sid=4b3a3 0cd-c7ec-4838-ba3c-48ce12f26813\%40sessionmgr12. Accessed 11 October 2013. 
[5] Daoji L and Dag D (2004), Ocean pollution from land-based sources: East China Sea. AMBIO- A Jr. of the Human Envt., 33(1/2): 107-113.

[6] Kenneth RW (2006), Plague of Plastic Chokes the Seas. Los Angeles Times Archived from http://www.pulitzer.org/year/2007/explanatory-

reporting/works/oceans04.html. Accessed 2008-04-01.

[7] Milkov AV (2004), Global estimates of hydrate-bound gas in marine sediments: how much is really out there? Earth Sci .Rev., 66(3-4): 183-197. Bibcode:2004ESRv...66..183M. doi:10.1016/j.earscirev. Accessed 2 November 2003.

[8] Rios LM, Moore C and Jones PR (2007), Persistent organic pollutants carried by Synthetic polymers in the ocean environment. Marine Pollut. Bull., 54(8): 1230-1237. doi:10.1016/j.marpolbul.2007.03.022. PMID 17532349.

[9] Stull JK (1989), Contaminants in sediments near a major marine outfall: history, effects and future. OCEANS '89 Proceedings 2: 481-484.

[10] Ogbuagu DH, Njoku JD and Ayoade AA (2011a), Trends in macrobenthal biotypes of Imo River in a Nigerian Delta region. Jr. Biodiv. Envir. Sci. (JBES), 1(4): 22-28. Available at http://www.innspub.net. Accessed 11 October 2013.

[11] Ogbuagu DH, Okoli CG, Emereibeole EI, Anyanwu IC, Onuoha O, Ubah NO, Ndugbu CO, Okoroama ON, Okafor A, Ewa E, Ossai R and Ukah F (2011b), Trace metals accumulation in biofilms of the upper and middle reaches of Otamiri river in Owerri, Nigeria. Jr. Biodiv. Envir. Sci. (JBES), 1(3): 19-26. Available at http://www.innspub.net . Accessed 10 October 2013.

[12] Kroeger T (2012), Dollars and Sense: Economic Benefits and Impacts from two Oyster Reef Restoration Projects in the Northern Gulf of Mexico. TNC Report. Retrieved from http://www.nature.org/ourinitiatives/regions/northamerica/oyst er-restoration-study-kroeger.pdf.

[13] Moore C, Moore SL, Leecaster MK and Weisberg SB (2001),
A Comparison of Plastic and Plankton in the North Pacific Central Gyre. Marine Pollut. Bullet., 42(12): 1297-1300. doi:10.1016/S0025-326X(01)00114-X. PMID 11827116.

[14] Newell RIE, Cornwell JC and Owens MS (2002), Influence of simulated bivalve biodepositon and microphytobenthos on sediment nitrogen dynamics, a laboratory study. Limnol. and Oceanogr., 47:1367-1379.

[15] Orr JC, Fabry VJ, Aumont O, Bopp L, Doney SC et al. (2005), Anthropogenic ocean acidification over the twenty-first century and its impact on calcifying organisms. Nature, 437 (7059): $\quad 681-686 . \quad$ Bibcode:2005Natur.437.681O. doi:10.1038/nature04095. ISSN 0028-0836. PMID 16193043.

[16] Tanabe S, Watanabe M, Minh TB, Kunisue T, Nakanishi S, Ono H and Tanaka H (2004), PCDDs, PCDFs, and coplanar PCBs in albatross from the North Pacific and Southern Oceans: Levels, patterns, and toxicological implications. Envir. Sci. \& Technol., 38 (2): 403-413. doi:10.1021/es034966x.

[17] Abowei JFN and Sikoki FD (2005), Water Pollution Management and Control. Doubletrust Publication Company, Port Harcourt, 236pp.

[18] Gerlach (1974), Marine Pollution, Springer, Berlin.

[19] Unlu S, Sari E, Apak R, Balci N and Koldemir B (2013), Distribution and source identification of polycyclic aromatic hydrocarbons in sediments of the Ambarli Port area, Sea of Marmara, Turkey. Global Adv. Res. Jr. Envir. Sci. Toxicol. (GARJEST), 2(6):144-151. Available online at http://garj.org/garjest/index.htm

[20] Chen CW and Chen CF (2011), Distribution, origin, and potential toxicological significance of polycyclic aromatic hydrocarbons (PAHs) in sediments of Kaohsiung Harbor, Taiwan. Mar. Pollut. Bull., 63: 417-423.

[21] Mostafa AR, Barakat AO, Qian Y and Wade TL (2003), Composition, distribution and sources of polycyclic aromatic hydrocarbons in sediments of the western harbour of Alexandria, Egypt. Jr. Soils Sed., 3: 173-179. 